\begin{tabular}{|c|c|}
\hline 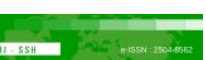 & Malaysian Journal of Social Sciences and Humanities (MJSSH) \\
\hline Malaysian Journal of & Volume 6, Issue 3, March 2021 \\
\hline (MJ-SSH) & e-ISSN : 2504-8562 \\
\hline & $\begin{array}{l}\text { Journal home page: } \\
\text { www.msocialsciences.com }\end{array}$ \\
\hline
\end{tabular}

\title{
Pengetahuan Penjaga Terhadap Amalan Penjagaan Ulser Tekanan Warga Tua Terlantar di Rumah
}

\author{
Normala Binti Riza ${ }^{1}$, Lukman @ Zawawi Bin Mohamad ${ }^{1}$ \\ ${ }^{1}$ Fakulti Sains Sosial Gunaan, Universiti Sultan Zainal Abidin (UniSZA) \\ Correspondence: Normala Binti Riza (normalariza@unisza.edu.my)
}

\begin{abstract}
Abstrak
Tujuan kajian ini dijalankan adalah untuk mengenal pasti tahap pengetahuan penjaga terhadap amalan penjagaan ulser tekanan warga tua terlantar di rumah. Seramai 127 orang penjaga telah dipilih sebagai responden dalam kajian ini. Kaedah kajian ini menggunakan kajian tinjauan dan instrumen yang digunakan ialah borang soal selidik. Data dalam kajian ini diuji dengan menggunakan statistik deskriptif yang melibatkan skor min dan sisihan piawai. Data dianalisis menggunakan perisian Statistical Package Social Science (SPSS) versi 22. Hasil kajian mendapati tahap pengetahuan penjaga terhadap amalan penjagaan ulser tekanan warga tua terlantar adalah rendah. Implikasi kajian ini adalah mencadangkan pembinaan satu amalan baik penjagaan ulser tekanan yang boleh diguna pakai oleh penjaga.
\end{abstract}

Kata kunci: ulser tekanan, warga tua terlantar, pengetahuan, amalan penjagaan

\section{Knowledge of Caregiver on the Pressure Ulcers Care Practices of Bedridden Elderly at Home}

\begin{abstract}
This study was conducted to identify the level of knowledge of caregiver on the pressure ulcers care practices of bedridden elderly at home. A total of 127 respondents were selected as respondents in this study. This research method uses survey research and the instrument used is a questionnaire. The data in this study were tested using descriptive statistics involving mean scores and standard deviations. Data were analyzed using Statistical Package Social Science (SPSS) version 22. The results of this study found that the level of knowledge of caregiver on the pressure ulcers care practices of bedridden elderly at home is at low. Implications in this study suggest to develop a pressure ulcers good care practice of the bedridden elderly at home.
\end{abstract}

Keywords: pressure ulcers, bedridden elderly, knowledge, care practice

\section{Pengenalan}

Rentetan dari peningkatan bilangan warga tua yang mempunyai penyakit kronik, bilangan warga tua yang terlantar telah berkembang pesat (Sharma et al., 2013). Daripada kesemua penyakit yang dihidapi 
oleh warga tua, sebanyak 70\% daripada mereka menjadi pesakit terlantar (Al-Shaali \& Al Jaziri, 2015). Ini menunjukkan peningkatan jangka hayat warga tua akan membawa kepada risiko penyakit kronik seterusnya akan menambahkan lagi bilangan warga tua yang sakit terlantar (Jiao et al., 2019).

Selepas sakit terlantar, warga tua juga berisiko untuk mendapat penyakit-penyakit lain. Risiko kesihatan yang paling biasa untuk pesakit terlantar adalah ulser tekanan dan sebanyak 50\% daripada pesakit terlantar mengalami ulser tekanan (Shuk-Fan, et al., 2016; Sharma et al., 2013). Ini disebabkan oleh tekanan yang berlaku kepada bahagian tulang yang menonjol (Livesley \& Chow, 2002: Yoshikawa, Livesley \& Chow, 2002). Kebanyakkkan warga tua sakit terlantar akan berada di atas katil lebih dari tempoh setahun (Wani dan Malik, 2013). Mahupun begitu, pesakit ini berisiko mendapat ulser tekanan setelah sekurang-kurangnya tiga minggu sakit terlantar (Chacon, et al., 2009).

Pesakit terlantar yang sentiasa menukar posisi badan mereka secara berkala membantu melancarkan pengaliran darah dan boleh mengelakkan terjadinya bisul (Wright, 2011). Berbaring dalam kedudukan yang sama untuk jangka masa yang panjang boleh menyekat pengaliran darah menyebabkan daging di bahagian ini mati dan ditambah dengan tekanan serta geseran pada kulit boleh membentuk luka yang sangat dalam jika tidak dirawat dengan baik (Chacon, et al., 2009; Shuk-Fan, et al., 2016; Ladan, et al., 2014). Ulser tekanan dengan mudah boleh dijangkiti dan menyebabkan komplikasi yang lebih serius sehingga amat penting bagi penjaga mengubah kedudukan pesakit terlantar secara berkala. Hal ini kerana ulser tekanan merupakan faktor kematian keempat bagi pesakit tua terlantar di rumah (Chacon, et al., 2009). Justeru, kesemua perkara penting ini perlu ada dalam pengetahuan penjaga terutamanya supaya penyakit-penyakit yang lebih serius dapat dielakkan.

\section{Sorotan Literatur}

Ulser tekanan juga dikenal sebagai ulser dekubitus, luka tekanan atau luka baring adalah masalah kesihatan yang lazimnya berlaku kepada pesakit yang tidak bergerak dan bergantung kepada penjagaan orang lain (Vanderwee, Grypdonck \& Defloor, 2008; Ladan et al., 2014; Shuk-Fan, 2016). Ulser tekanan juga kerap berlaku pada warga tua yang terbaring di tempat tidur, kerusi roda dan individu dalam perawatan jangka panjang (Shuk-Fan, 2016). Lazimnya, faktor utama ulser tekanan kepada warga tua ialah disebabkan oleh faktor risiko yang berkaitan dengan usia tua seperti penurunan mobiliti, gaya hidup yang aktif, pendedahan badan kepada tekanan dan status pemakanan yang buruk (Donini, et al., 2005). Masalah ulser tekanan ini adalah serius kerana ia merupakan kecederaan setempat pada kulit dan tisu yang biasanya disebabkan oleh tulang yang menonjol, tekanan dan/atau ricih (Margolis et al., 2006; Ladan et al., 2014; Liu et al., 2014; National Pressure Injury Advisory Panel, 2016; Edsberg et al., 2016).

Skala penilaian risiko untuk mengenal pasti risiko ulser tekanan adalah halangan untuk menentukan risiko dan memberikan rawatan yang tepat kepada pesakit (Keller et al., 2002; De Laat et al., 2006; Cox, 2011). Menurut Ladan et al. (2014), sekiranya keadaan pesakit tidak dirawat dengan cepat, kerosakan kulit di bahagian tersebut akan merebak ke lapisan tisu yang lebih dalam dan akan menjejaskan otot, tendon dan tulang. Masalah ini boleh menyebabkan kesakitan, jangkitan, kemurungan, penurunan kualiti kehidupan, kos rawatan yang tinggi dan akhirnya boleh membawa kematian (Iizaka et al., 2010; Holmes, 2010; Campbell, Woodbury \& Houghton, 2010; Alhosis, Qalawa \& Abd El-Moneem, 2012; Saghaleini et al., 2018).

Menukar posisi pesakit adalah langkah utama dalam kebanyakan protokol pencegahan ulser tekanan di mana mengesyorkan pesakit ditukar kedudukan setiap dua jam (Liu et al., 2014). Tujuan penukaran posisi adalah untuk mengurangkan atau menghilangkan tekanan antara permukaan kulit dan dengan itu menjaga peredaran mikro ke kawasan badan yang berisiko mengalami ulser tekanan (Reddy, Gill \& Rochon, 2006). Amalan menukar posisi pesakit terlantar juga perlulah menggunakan kaedah yang betul (Wound, 2017). Penggunaan alatan seperti katil angin dan kain alas merupakan satu kaedah yang efektif untuk mengurangkan risiko luka paka kulit selain menghindarkan kesakitan semasa melakukan penukaran posisi atau pemindahan pesakit (Kwiczala-Szydłowska, Skalska \& Grodzicki (2005). 
Status pemakanan adalah faktor yang penting dalam proses penyembuhan ulser tekanan (Donini, et al., 2005). Iizaka et al. (2010) mengatakan bahawa kekurangan zat makanan mempunyai nisbah kemungkinan tertinggi berbanding semua faktor risiko ulser tekanan yang lain. Oleh itu, sekiranya risiko pemakanan atau kekurangan zat makanan berlaku, pesakit berisiko tinggi untuk mengalami atau sukar untuk pulih daripada ulser tekanan (Houwing et al., 2003; Mathus-Vliegen, 2004). Peningkatan protein dalam diet (daging, telur, produk tenusu, kekacang), kalori, karbohidrat, lemak, vitamin dan mineral setiap hari membantu memenuhi keperluan tenaga dan pertumbuhan sel baru (Stechmiller, 2008; Sharma et al., 2013, Saghaleini et al., 2018). Justeru, aspek pemakanan akan menjadi sangat penting sebagai penjagaan bagi mencegah dan merawat ulser tekanan (Iizaka et al., 2010). Penghidratan juga memainkan peranan penting dalam pemeliharaan dan pembaikan integriti kulit. Dehidrasi mengganggu metabolisme sel dan penyembuhan luka. Pengambilan cairan yang mencukupi diperlukan untuk menyokong aliran darah ke tisu yang cedera dan untuk mengelakkan kerosakan kulit tambahan (Saghaleini et al., 2018).

\section{Metod Kajian}

Kajian ini menggunakan pendekatan kuantitatif dengan menggunakan kaedah tinjauan sebagai reka bentuk kajian. Penyelidikan kuantitatif merupakan kajian yang menggunakan statistik yang melibatkan bilangan responden yang banyak dengan sekurang-kurangnya melebihi 10 sampel dalam mengukur pemboleh ubah bagi sesuatu penyelidikan tersebut (Krejcie \& Morgan, 1970; Cohen, 1992). Penentuan saiz sampel dalam kajian ini adalah berasaskan kaedah yang digunakan oleh Cohen (1992) dan perisian G*power 3.1. Justeru, seramai 127 orang sampel telah dijadikan responden di dalam kajian ini.

Kaedah pengumpulan data adalah melalui soal selidik. Data yang dikumpulkan terdiri daripada 20 soalan dengan lima bentuk kekerapan dan diukur dengan skala likert berskala 1 hingga 5 iaitu dari "tidak pernah" kepada "sangat kerap". Soalan dibina merangkumi aspek penjagaan kulit, pergerakan fizikal serta penjagaan pemakanan bagi pesakit yang mempunyai ulser tekanan (Eljedi et al., 2015; Alhosis, Qalawa \& Abd El-Moneem, 2012). Bagi memastikan instrumen soal selidik ini boleh diguna pakai, satu kajian rintis telah diadakan terhadap 40 orang responden. Hasil ujian Cronbach Alpha pada Jadual 1 menunjukkan indeks kepercayaan bagi tahap pengetahuan amalan penjagaan ulser tekanan ialah 0.83 bagi analisis kebolehpercayaan Cronbach Alpha terhadap kajian sebenar adalah 0.93

Jadual 1: Ujian Kebolehpercayaan Cronbach Alpha

\begin{tabular}{lccc}
\hline \multicolumn{1}{c}{ Pemboleh ubah } & $\begin{array}{c}\text { Bilangan } \\
\text { Item }\end{array}$ & $\begin{array}{c}\text { Kajian } \\
\text { Rintis } \\
(\mathbf{n = 4 0})\end{array}$ & $\begin{array}{c}\text { Kajian } \\
\text { Sebenar } \\
(\mathbf{n}=\mathbf{1 2 7})\end{array}$ \\
\hline $\begin{array}{l}\text { Tahap pengetahuan terhadap amalan penjagaan ulser } \\
\text { tekanan }\end{array}$ & 20 & 0.83 & 0.93 \\
\hline
\end{tabular}

Dalam kajian ini, data analisis melibatkan analisis statistik deskriptif yang melibatkan skor min dan sisihan piawaian dalam penentuan tahap pengetahuan penjaga tentang amalan penjagaan ulser tekanan warga tua terlantar di rumah. Skor min diukur berdasarkan interpretasi skor min oleh Pallant (2007). Jadual 2 menunjukkan Pallant (2007) membahagikan nilai skor min kepada tiga tahap iaitu nilai skor min 1.00 hingga 2.33 adalah pada tahap rendah, nilai skor min 2.34 hingga 3.66 adalah pada tahap sederhana, dan nilai skor min 3.67 hingga 5.00 adalah pada tahap tinggi. Menurut Pallant (2007), skor min tiga tahap ini adalah lebih sesuai dan lebih mudah untuk melihat perbezaan tahap.

Jadual 2: Skor min dan interpretasinya

\begin{tabular}{cc}
\hline Skor min & Interpretasi (tahap pengetahuan) \\
\hline $1.00-2.33$ & Rendah \\
$2.34-3.66$ & Sederhana \\
\hline
\end{tabular}



$3.67-5.00$
Tinggi

Sumber: Pallant (2007)

\section{Hasil Kajian}

Berdasarkan Jadual 3, skor min bagi tahap pengetahuan tentang amalan penjagaan ulser tekanan warga tua terlantar adalah rendah iaitu $\mathrm{M}=2.21$ dan $\mathrm{SP}=1.001$. Bagi amalan-amalan yang menunjukkan tahap pengetahuan yang rendah pula ialah amalan memastikan pemeriksaan sentiasa dibuat terhadap kewujudan ulser tekanan sekurang-kurangnya sekali sehari $(\mathrm{M}=2.10, \mathrm{SP}=1.140)$, memastikan buku lali dan lutut saling tidak bersentuhan antara satu sama lain dengan menggunakan bantal atau kusyen (M $=1.89, \mathrm{SP}=1.121)$ dan membantu warga tua menukar posisi badan setiap dua jam (terlantar di katil) atau satu jam (kerusi roda) $(\mathrm{M}=1.83, \mathrm{SP}=1.141)$.

Penggunaan tilam khas bagi pesakit terlantar sangat penting kerana fungsinya yang dapat mengurangkan risiko terjadinya ulser tekanan. Walau bagaimanapun, min skor bagi tahap pengetahuan penjaga tentang penggunaan tilam khas untuk pesakit terlantar juga didapati rendah iaitu $(\mathrm{M}=1.67, \mathrm{SP}=1.316)$. Selain itu, skor min bagi tahap pengetahuan tentang amalan memastikan pembersih ringan digunakan untuk mengurangkan kekeringan dan kerengsaan pula ialah $\mathrm{M}=1.45$ dan $\mathrm{SP}=.990$ manakala amalan menggunakan krim perlindungan kulit yang disyorkan $(\mathrm{M}=1.43, \mathrm{SP}=.930)$.

Bagi amalan-amalan lain yang juga menunjukkan skor min tahap pengetahuan rendah termasuk amalan memastikan warga tua diberikan makanan yang disarankan oleh pakar pemakanan atau doktor $(\mathrm{M}=1.20$, $\mathrm{SP}=.671)$, memastikan kain linen kering dan tidak berkedut semasa diletakkan di bawah badan warga tua $(\mathrm{M}=1.18, \mathrm{SP}=.706)$, merujuk doktor sekiranya terdapat tanda-tanda ulser tekanan $(\mathrm{M}=1.17, \mathrm{SP}=$ .601), menggunakan kain linen atau alat bantuan untuk menukar posisi warga ketika berada di atas katil $(\mathrm{M}=1.17, \mathrm{SP}=.601)$, merujuk pakar diet mengenai pengambilan makanan yang sesuai untuk warga tua yang berisiko atau mempunyai ulser tekanan $(\mathrm{M}=1.09, \mathrm{SP}=.387)$.

Jadual 3: Skor Min dan Sisihan Piawai Tahap Pengetahuan Penjaga

Tentang Amalan Penjagaan Ulser Tekanan

\begin{tabular}{|c|c|c|c|c|}
\hline Bil. & Perkara & $\begin{array}{l}\text { Min } \\
(\mathrm{M})\end{array}$ & $\begin{array}{l}\text { Sisihan } \\
\text { Piawai } \\
\text { (SP) }\end{array}$ & Tahap \\
\hline 1 . & $\begin{array}{l}\text { Memastikan pemeriksaan sentiasa dibuat terhadap kewujudan } \\
\text { ulser tekanan sekurang-kurangnya sekali sehari. }\end{array}$ & 2.10 & 1.140 & Rendah \\
\hline 2. & Merujuk doktor sekiranya terdapat tanda-tanda ulser tekanan. & 1.17 & .601 & Rendah \\
\hline 3. & $\begin{array}{l}\text { Membantu warga tua menukar posisi badan setiap dua jam } \\
\text { (terlantar dikatil)/ satu jam (kerusi roda). }\end{array}$ & 1.83 & 1.141 & Rendah \\
\hline 4. & $\begin{array}{l}\text { Memastikan buku lali dan lutut saling tidak bersentuhan } \\
\text { antara satu sama lain dengan menggunakan bantal atau } \\
\text { kusyen. }\end{array}$ & 1.89 & 1.121 & Rendah \\
\hline & $\begin{array}{l}\text { Memastikan warga tua tidak diseret semasa melakukan } \\
\text { pemindahan atau penukaran posisi. }\end{array}$ & 3.09 & 1.354 & Sederhana \\
\hline 6. & Memastikan kulit warga tua sentiasa kering. & 3.21 & 1.289 & Sederhana \\
\hline & $\begin{array}{l}\text { Memastikan kulit warga tua dibersihkan segera sekiranya } \\
\text { terdapat kotoran. }\end{array}$ & 3.27 & 1.080 & Sederhana \\
\hline & $\begin{array}{l}\text { Memastikan pembersih ringan digunakan untuk } \\
\text { mengurangkan kekeringan dan kerengsaan. }\end{array}$ & 1.45 & .990 & Rendah \\
\hline 9. & Menggunakan krim perlindungan kulit yang disyorkan. & 1.43 & .930 & Rendah \\
\hline
\end{tabular}


DOI: https://doi.org/10.47405/mjssh.v6i3.714

10. Memastikan bahagian berisiko mengalami ulser tekanan tidak 2.8 diurut/digosok.

11. Menggunakan lampin pakai buang dengan permukaan cepat
kering.

12. Memastikan lampin pakai buang ditukar sekiranya terdapat kotoran.

13. Memastikan pakaian bersih ditukar setiap hari.

$3.43 \quad 1.073 \quad$ Sederhana

14. Memastikan alas tilam sentiasa ditukar.

$3.35 \quad 1.102 \quad$ Sederhana

15. Menggunakan tilam khas untuk pesakit terlantar.

16. Menggunakan kain linen/alat bantuan untuk menukar posisi warga ketika berada di atas katil.

17. Memastikan kain linen kering dan tidak berkedut semasa diletakkan di bawah badan warga tua.

18. Memastikan warga tua diberikan air yang mencukupi setiap hari.

19. Merujuk pakar diet mengenai pengambilan makanan yang sesuai untuk warga tua yang berisiko/mempunyai ulser tekanan.

20. Memastikan warga tua diberikan makanan yang disarankan oleh pakar pemakanan/doktor.

Jumlah

$3.13 \quad 1.091 \quad$ Sederhana

$2.74 \quad .9613 \quad$ Sederhana

$1.67 \quad 1.316 \quad$ Rendah

$1.17 \quad .687 \quad$ Rendah

$1.18 \quad .706 \quad$ Rendah

$3.00 \quad 992 \quad$ Sederhana

$1.09 \quad .387 \quad$ Rendah

$1.20 \quad .671 \quad$ Rendah

$2.21 \quad 1.001 \quad$ Rendah

Jadual 3 juga menunjukkan beberapa amalan yang mempunyai tahap pengetahuan yang sederhana. Antaranya ialah amalan menggunakan lampin pakai buang dengan permukaan cepat kering $(\mathrm{M}=3.43$, $\mathrm{SP}=1.073)$, memastikan lampin pakai buang ditukar sekiranya terdapat kotoran $(\mathrm{M}=3.35, \mathrm{SP}=1.102)$, memastikan kulit warga tua dibersihkan segera sekiranya terdapat kotoran $(\mathrm{M}=3.27, \mathrm{SP}=1.080)$, memastikan kulit warga tua sentiasa kering $(\mathrm{M}=3.21$, $\mathrm{SP}=1.289)$, memastikan pakaian bersih ditukar setiap hari $(\mathrm{M}=3.13, \mathrm{SP}=1.091)$, memastikan warga tua tidak diseret semasa melakukan pemindahan atau penukaran posisi $(\mathrm{M}=3.03, \mathrm{SP}=1.354)$, memastikan warga tua diberikan air yang mencukupi setiap hari $(\mathrm{M}=3.00, \mathrm{SP}=.992)$, memastikan bahagian berisiko mengalami ulser tekanan tidak diurut atau digosok $(\mathrm{M}=2.87, \mathrm{SP}=1.399)$ dan memastikan alas tilam sentiasa ditukar $(\mathrm{M}=2.74, \mathrm{SP}=.9613)$. Ringkasnya, pengetahuan yang berada pada tahap sederhana dilihat mempunyai kaitan dengan aktiviti harian penjaga dalam menguruskan warga tua terlantar. Disebabkan rutin harian penjaga menguruskan kebersihan diri warga tua serta membersihkan tempat tidur menunjukkan mereka mempunyai pengetahuan tentang amalan penjagaan warga tua.

Mahupun begitu, secara keseluruhannya tahap pengetahuan penjaga terhadap amalan penjagaan ulser tekanan hanya berada pada tahap rendah sahaja. Tambahan lagi lebih daripada separuh penjaga mempunyai pengetahuan yang rendah tentang amalan penjagaan ulser tekanan. Jadual 4 menunjukkan penjaga yang mempunyai pengetahuan yang rendah tentang amalan penjagaan ulser tekanan warga tua terlantar mencatat jumlah tertinggi iaitu seramai 76 orang (59.8\%). Manakala penjaga yang mempunyai pengetahuan sederhana pula ialah seramai 47 orang (37\%). Seterusnya, hanya 4 orang $(3.1 \%)$ penjaga sahaja yang mempunyai pengetahuan yang tinggi terhadap amalan penjagaan ulser tekanan.

Jadual 4: Kekerapan Penjaga Mengikut Tahap Pengetahuan Terhadap Amalan Penjagaan Ulser Tekanan Warga Tua Terlantar

\begin{tabular}{lcc}
\multicolumn{1}{c}{ Tahap Pengetahuan } & Kekerapan & Peratus (\%) \\
\hline Rendah & 76 & 59.8 \\
Sederhana & 47 & 37.0 \\
Tinggi & 4 & 3.1 \\
\hline
\end{tabular}




\begin{tabular}{lcc}
\hline Jumlah & 127 & 100.0 \\
\hline
\end{tabular}

\section{Perbincangan Kajian}

Ulser tekanan adalah luka yang biasa berlaku kepada pesakit terlantar (Kaur et al., 2018). Ini disebabkan oleh tekanan yang berlaku kepada bahagian tulang yang menonjol (Livesley \& Chow, 2002: Yoshikawa, Livesley dan Chow, 2002). Pengetahuan terhadap penjagaan ulser tekanan dalam kajian ini difokuskan kepada empat bahagian iaitu penjagaan kulit (rawatan ulser dan pakaian), kebersihan diri, posisi yang betul dan pemakanan (Eljedi et al., 2015; Alhosis, Qalawa \& Abd El-Moneem, 2012).

Secara keseluruhannya, tahap pengetahuan penjaga terhadap amalan penjagaan ulser tekanan adalah rendah. Kenyataan ini juga disokong oleh kajian Kaur et al., 2018 di mana penjaga mempunyai cabaran dalam menjaga warga tua terlantar yang mempunyai ulser tekanan kerana mereka tidak mempunyai pengetahuan dan tidak terlatih untuk berada dalam situasi tersebut. Manakala kajian Tier et al. (2019) mengatakan penjaga hanya mempunyai sedikit pengetahuan dan memerlukan maklumat tentang kecederaan kulit seperti ulser tekanan supaya dapat memberikan rawatan di rumah dan langkah pencegahan dengan baik. Juga dalam kajian lain yang dilakukan oleh Sharma et al. (2013) mengenai amalan penjagaan ulser tekanan, didapati bahawa penjaga tidak tahu bagaimana untuk menguruskan pesakit terlantar yang mempunyai ulser tekanan. Mereka membiarkan pesakit mereka terbaring dalam keadaan tidak selesa sehingga menyebabkan keadaan ulser tekanan semakin teruk.

Majoriti penjaga tidak merujuk kepada doktor apabila terdapat tanda-tanda ulser tekanan pada warga tua terlantar. Disebabkan pengetahuan yang rendah, tanda-tanda awal ulser yang wujud tidak dipandang serius oleh penjaga dan ini boleh menyebabkan masalah ulser tekanan menjadi semakin serius. Kenyataan ini disokong oleh kajian Eljedi, ElDaharja dan Dukhan (2015) yang mengatakan bahawa sebilangan besar tanda ulser tekanan yang dilaporkan mempunyai bintik hitam, nanah dan bau busuk. Kehadiran tanda-tanda ini menunjukkan pengabaian dan kelewatan merawat ulser tekanan. Selain itu, kajian Sharma et al.(2013) mengatakan penjaga tidak menyedari tanda-tanda awal ulser pada bahagian yang sukar dilihat dan ini merupakan salah satu sebab mengapa penjaga tidak menyedari kewujudan ulser ini di peringkat awal. Ini menggambarkan tanpa pengetahuan, penjaga tidak mempunyai kesedaran akan risiko kewujudan ulser terkanan kepada warga tua terlantar. Justeru, keperluan untuk pendidikan dan latihan untuk meningkatkan kesedaran dan pengetahuan tentang pencegahan dan penjagaan ulser tekanan amatlah perlu.

Menukar posisi pesakit adalah langkah utama dalam kebanyakan protokol pencegahan ulser tekanan di mana mengesyorkan pesakit ditukar kedudukan setiap dua jam (Reddy et al., 2006; Liu et al., 2014). Namun, dapatan kajian ini mendapati penjaga gagal melakukan amalan tersebut kerana dapatan menunjukkan tahap pengetahuan penjaga terhadap amalan penukaran posisi warga tua terlantar setiap dua jam didapati rendah. Walaupun 75.6\% daripada responden kajian Poudyal (2014) mengatakan mereka mempunyai pengetahuan mengenai perubahan kedudukan yang kerap, namun kajian ini tidak menyatakan kekerapan perubahan kedudukan perlu dilakukan. Kajian Jaul (2010) pula menyatakan bahawa duduk yang berpanjangan dan tidak menukar posisi warga tua terlantar boleh mewujudkan luka terutama pada bahagian yang berisiko.

Selain itu, pengetahuan penjaga terhadap amalan penjagaan kulit warga tua bagi mengelakkan atau merawat ulser tekanan dilaporkan berada pada tahap sederhana. Antara amalan yang digariskan dalam kajian ini ialah memastikan warga tua tidak diseret semasa melakukan pemindahan atau penukaran posisi, memastikan kulit warga tua sentiasa kering, memastikan kulit warga tua dibersihkan segera sekiranya terdapat kotoran, memastikan bahagian berisiko mengalami ulser tekanan tidak diurut atau digosok, menggunakan lampin pakai buang dengan permukaan cepat kering, memastikan lampin pakai buang ditukar sekiranya terdapat kotoran, memastikan pakaian dan tilam bersih sentiasa ditukar. Jaul (2010) mengatakan, kelembapan boleh dikurangkan sekiranya penjaga menukar lampin dengan lebih kerap dan menggunakan krim pada kulit mereka. Selain itu, penjaga seharusnya segera membersihkan 
anggota badan warga tua sekiranya terdapat kotoran dan memastikan kulit mereka berada dalam keadaan kering (Wound, 2017).

Dalam aspek amalan menggunakan alatan bagi merawat atau mencegah ulser tekanan seperti tilam khas dan penggunaan kain linen untuk memudahkan proses menukar posisi atau memindahkan warga tua terlantar, penjaga didapati mempunyai pengetahuan yang rendah. Penemuan serupa dilaporkan oleh Kwiczala-Szydłowska et al. (2005) bahawa kebanyakan penjaga tidak mengetahui prinsip asas pencegahan termasuk alat yang berguna dalam pencegahan ulser tekanan, tidak mengetahui mengenai tilam mengurangkan tekanan dan kajian menyimpulkan bahawa pesakit terlantar tidak mempunyai pengetahuan yang mencukupi mengenai pencegahan ulser tekanan. Penggunaan tilam kurang tekanan sangat mempengaruhi risiko pembentukan ulser tekanan (Cullum et al., 2000). Kenyataan ini disokong oleh Stechmiller (2008) yang mengatakan menukar posisi setiap empat jam dengan penggunaan tilam pengurangan tekanan terbukti dapat mengurangkan risiko terjadinya ulser tekanan berbanding dengan menukar posisi setiap dua hingga empat jam dengan penggunaan tilam dengan tekanan. Selain itu, penjaga digalakkan menggunakan kain linen untuk mengangkat atau memindahkan warga tua agar tidak terseret atau berlaku geseran yang mengakibatkan luka pada kulit (Wound, 2017).

Faktor pemakanan tertentu seperti pengambilan nutrient dan protein terjejas, kemerosotan status pemakanan dan kekurangan zat makanan sering dikaitkan dengan perkembangan ulser tekanan (Bergstrom dan Braden, 1992; Allman et al., 1995; Donini et al., 2005). Sekiranya warga tua yang mengalami ulser tekanan dikenal pasti mempunyai kaitan dengan kekurangan zat makanan (diet yang tidak sihat, pengambilan protein yang rendah), maka pakar pemakanan atau perunding diet perlu campur tangan (Barczak et al., 1997). Justeru, penjaga terutamanya perlu mempunyai kesedaran terhadap keperluan ini supaya masalah ulser tekanan yang dihadapi oleh warga tua dapat dirawat atau dicegah dengan lebih awal. Walau bagaimanapun, kajian ini mendapati pengetahuan penjaga terhadap amalan penjagaan pemakanan warga tua terlantar adalah rendah. Penjaga didapati tidak merujuk pakar diet mengenai pengambilan makanan yang sesuai untuk warga tua yang berisiko atau mempunyai ulser tekanan dan tidak atau kurang memberikan makanan yang sesuai sepertimana disarankan oleh pakar pemakanan atau doktor. Dapatan ini disokong dengan kajian Iizaka et al (2010) yang mengatakan empat per lima penjaga tidak mempunyai pengetahuan tentang pemakanan pesakit ulser tekanan.

Oleh itu, disimpulkan bahawa pengetahuan penjaga mengenai amalan penjagaan ulser tekanan tidak mencukupi. Sebilangan besar iaitu $59.8 \%$ dan $37 \%$ penjaga masing-masing mempunyai pengetahuan yang rendah dan sederhana. Faktor yang menyebabkan situasi ini adalah kerana kekurangan latihan dalam penjagaan warga tua terlantar menyebabkan kualiti penjagaan yang rendah dan kadar komplikasi yang tinggi dalam kes terlantar di tempat tidur (Sharma et al., 2013). Sehubungan itu, pendidikan tentang penjagaan ulser tekanan perlu diberikan kepada penjaga supaya mereka boleh mencegah dan merawat pesakit terlantar di rumah dan kerjasama profesional kesihatan dengan penjaga juga mungkin sangat diperlukan.

\section{Kesimpulan}

Tahap pengetahuan penjaga dalam kajian ini didapati adalah rendah dan sederhana. Penjaga dilihat mempunyai tahap pengetahuan yang sederhana terhadap amalan penjagaan kebersihan diri, pemakanan dan kesihatan emosi. Manakala dalam aspek amalan latihan pergerakan fizikal dan penjagaan ulser tekanan, penjaga mempunyai tahap pengetahuan yang rendah. Menurut Kissal et al. (2019), penjaga mengalami kesulitan dalam merawat pesakit yang mempunyai ulser tekanan dan mencegah daripada terjadinya ulser tekanan, membersihkan luka ulser tekanan dan membawa pesakit dengan kaedah yang sesuai, penjagaan alat kelamin, pengurusan tekanan dan sembelit. Manakala kajian Maheshwari dan Mahal (2016) melaporkan bahawa $81 \%$ penjaga dalam kajian mereka tidak mempunyai latihan yang mencukupi dan tidak pernah mendapat pendidikan formal untuk kemahiran dan pengetahuan penjagaan.

Penjaga berada dalam rangkaian autonomi yang belum menjadi sebahagian daripada perkhidmatan formal dan mereka juga kekurangan orientasi dan sokongan dari profesional kesihatan (Medeiros, Félix \& da Nóbrega, 2016). Kapucu, Turkan dan Fesci, (2009) menyatakan bahawa penjaga yang merawat 
pesakit terlantar mempunyai kekurangan pengetahuan mengenai perawatan fizikal, diet, ubat-ubatan, penyakit, senaman, perawatan ulser tekanan dan fungsi sistem perkumuhan pesakit. Profesional kesihatan biasanya tidak menilai pengetahuan dan kemahiran penjaga untuk membantu warga tua dalam aktiviti seperti memberi makan, kebersihan diri, pergerakan dan aktiviti fizikal (Wolff, Feder dan Schulz, 2016). Akibatnya, ramai penjaga belajar melalui try and error yang boleh menyebabkan ketakutan dan kegelisahan kerana bimbang kaedah penjagaan mereka membahayakan orang warga tua yang dijaga (Wolff, Feder \& Schulz, 2016). Oleh itu, rawatan hospital juga seharusnya merangkumi pendidikan penjagaan dan rawatan untuk pesakit dan penjaga tentang amalan penjagaan yang betul di rumah. Penjaga memainkan peranan penting dalam menguruskan semua aspek perawatan pesakit (Poudyal, Neupane \& Lopchan, 2014). Mereka adalah orang yang selalu bersama pesakit daripada doktor dan jururawat. Oleh itu, pengetahuan penjaga mengenai langkah-langkah umum seperti posisi, senaman, penjagaan kulit, pemakanan dan sokongan akan meningkatkan kualiti hasil dan mencegah komplikasi (Turkoglu \& Kilıc, 2012).

Menguruskan pesakit terlantar adalah pekerjaan yang sukar dan banyak penjaga menunjukkan tekanan dan tuntutan psikologi dalam kesihatan fizikal dan mental, terutamanya apabila memberikan penjagaan berterusan selama lebih dari satu tahun. Sekiranya pengetahuan yang mencukupi diberikan kepada pemberi penjagaan, ianya akan membantu mereka mengatasi tekanan dan meningkatkan kualiti hidup mereka dan warga tua (Crist, 2005). Justeru, satu garis panduan penjagaan perlu dibentuk untuk penjaga meningkatkan pengetahuan penjagaan dan kualiti penjagaan warga tua mereka.

\section{Rujukan}

Alhosis, K., Qalawa, S., \& Abd El-Moneem, D. (2012). Effect of designed pressure ulcer prevention program on caregivers' knowledge of immobilized patients. Journal of American Science, 8(12), 939-948.

Al-Shaali, A., \& Al Jaziri, A. (2015). Health profile of elderly patients registered in the elderly home based primary care, Dubai, United Arab Emirates. Middle East Journal of Age and Ageing, 83(1642), 1-7.

Barczak, C. A., Barnett, R. I., Childs, E. J., \& Bosley, L. M. (1997). Fourth national pressure ulcer prevalence survey. Advances in wound care: the journal for prevention and healing, 10(4), 1826.

Bergstrom, N., \& Braden, B. (1992). A prospective study of pressure sore risk among institutionalized elderly. Journal of the American Geriatrics Society, 40(8), 747-758. https://doi.org/10.1111/j.1532-5415.1992.tb01845.x.

Campbell, K. E., Woodbury, M. G., \& Houghton, P. E. (2010). Implementation of best practice in the prevention of heel pressure ulcers in the acute orthopedic population. International wound journal, 7(1), 28-40. https://doi.org/10.1111/j.1742-481X.2009.00650.x.

Chacon, J. M. F., Blanes, L., Hochman, B., \& Ferreira, L. M. (2009). Prevalence of pressure ulcers among the elderly living in long-stay institutions in São Paulo. Sao Paulo Medical Journal, 127(4), 211-215. https://doi.org/10.1590/S1516-31802009000400006.

Cohen, J. (1992). Statistical power analysis. Current directions in psychological science, 1(3), 98-101. https://doi.org/10.1111\%2F1467-8721.ep10768783.

Cox, J. (2011). Predictors of pressure ulcers in adult critical care patients. American journal of critical care, 20(5), 364-375. https://doi.org/10.4037/ajcc2011934.

Crist, J. D. (2005). The meaning for elders of receiving family care. Journal of Advanced Nursing, 49(5), 485-493. https://doi.org/10.1111/j.1365-2648.2004.03321.x.

Cullum, N. A., Deeks, J., Sheldon, T. A., Song, F., \& Fletcher, A. W. (2000). Beds, mattresses and cushions for pressure sore prevention and treatment. Cochrane Database of Systematic Reviews, (2). https://doi.org/10.1002/14651858.CD001735.

De Laat, E. H. E. W., Schoonhoven, L., Pickkers, P., Verbeek, A. L. M., \& van Achterberg, T. (2006). Epidemiology, risk and prevention of pressure ulcers in critically ill patients: a literature review. Journal of wound care, 15(6), 269-275.

https://doi.org/10.12968/jowc.2006.15.6.26920. 
Donini, L. M., De Felice, M. R., Tagliaccica, A., De Bernardini, L., \& Cannella, C. (2005). Nutritional status and evolution of pressure sores in geriatric patients. Journal of Nutrition Health And Aging, 9(6), 446.

Edsberg, L. E., Black, J. M., Goldberg, M., McNichol, L., Moore, L., \& Sieggreen, M. (2016). Revised national pressure ulcer advisory panel pressure injury staging system: revised pressure injury staging system. Journal of Wound, Ostomy, and Continence Nursing, 43(6), 585. doi: 10.1097/WON.0000000000000281.

Eljedi, A., ElDaharja, T., \& Dukhan, N. (2015). Effect of an educational program on a family caregiver's prevention and management of pressure ulcers in bedridden patients after discharge from hospitals in Palestine. Int $J$ Med Sci Public Heal [Internet], 4(5), 600. DOI: 10.5455/ijmsph.2015.20012015120.

Holmes, A. M. (2010). Another look: Best practices for pressure ulcer prevention. Nursing management, 41(1), 15-16. doi: 10.1097/01.NUMA.0000366897.78739.c9.

Houwing, R. H., Rozendaal, M., Wouters-Wesseling, W., Beulens, J. W. J., Buskens, E., \& Haalboom, J. R. (2003). A randomised, double-blind assessment of the effect of nutritional supplementation on the prevention of pressure ulcers in hip-fracture patients. Clinical Nutrition, 22(4), 401-405. https://doi.org/10.1016/S0261-5614(03)00039-6.

Iizaka, S., Okuwa, M., Sugama, J., \& Sanada, H. (2010). The impact of malnutrition and nutritionrelated factors on the development and severity of pressure ulcers in older patients receiving home care. Clinical Nutrition, 29(1), 47-53. https://doi.org/10.1016/j.clnu.2009.05.018.

Jaul, E. (2010). Assessment and Management of Pressure Ulcers in the Elderly: Current Strategies. Drugs \& Aging. 7 (4): 311-325. 10.2165/11318340-000000000-00000.

Kıssal, A., Kurt, G., Koç, M., Çıtıl, R., Gülpınar, S., \& Önder, Y. (2019). Knowledge and skill needs of home caregivers and their care burden perceptions. Journal of Human Sciences, 16(3), 833-845. doi:10.14687/jhs.v16i3.5610.

Keller, P. B., Wille, J., van Ramshorst, B., \& van der Werken, C. (2002). Pressure ulcers in intensive care patients: a review of risks and prevention. Intensive care medicine, 28(10), 1379-1388. https://doi.org/10.1007/s00134-002-1487-z.

Ladan, A. M., Garba, S. N., Sani, D. K., Sani, H. M., \& Muhammed, A. F. (2014). Pressure Ulcer Stages among Bed-Ridden Patients in Ahmadu Bello University Teaching Hospital (ABUTH), ZariaNigeria. IOSR Journal of Nursing and Health Science, 3(1). https://doi.org/10.9790/195903146168.

Liu, J. J., Huang, M. C., Xu, W., \& Sarrafzadeh, M. (2014, August). Bodypart localization for pressure ulcer prevention. In 2014 36th annual international conference of the ieee engineering in medicine and biology society (pp. 766-769). IEEE. 10.1109/EMBC.2014.6943703.

Livesley, N. J., \& Chow, A. W. (2002). Infected pressure ulcers in elderly individuals. Clinical infectious diseases, 1390-1396.

Kaur, S., Singh, A., Tewari, M. K., \& Kaur, T. (2018). Comparison of two intervention strategies on prevention of bedsores among the bedridden patients: A quasi experimental community-based trial. Indian journal of palliative care, 24(1), 28. doi: 10.4103/IJPC.IJPC_60_17.

Krejcie, R. V., \& Morgan, D. W. (1970). Determining sample size for research activities. Educational and psychological measurement, 30(3), 607-610. https://doi.org/10.1177\%2F001316447003000308.

Kwiczala-Szydłowska, S., Skalska, A., \& Grodzicki, T. (2005). Pressure ulcer prevention — evaluation of awarness in families of patients at risk. Przeglad lekarski, 62(12), 1393-1397.

Maheshwari, P. S., \& Mahal, R. K. (2016). Relationship of preparedness and burden among family caregivers of cancer patients in India. Journal of Health, Medicine and Nursing, 22, 35-44.

Margolis, D. J., Bilker, W., Knauss, J., Baumgarten, M., \& Strom, B. L. (2002). The incidence and prevalence of pressure ulcers among elderly patients in general medical practice. Annals of epidemiology, 12(5), 321-325. https://doi.org/10.1016/S1047-2797(01)00255-1.

Mathus-Vliegen, E. M. (2004). Old age, malnutrition, and pressure sores: an ill-fated alliance. The Journals of Gerontology Series A: Biological Sciences and Medical Sciences, 59(4), M355M360. https://doi.org/10.1093/gerona/59.4.M355. 
Medeiros, F. D. A. L., Félix, L. G., \& da Nóbrega, M. M. L. (2016). Clinical Caritas Processes in workshops for caregivers of institutionalized elderly people. Revista brasileira de enfermagem, 69(6), 997. http://dx.doi.org/ 10.1590/0034-7167-2016-0359.

National Pressure Injury Advisory Panel. (2016). NPIAP Pressure Injury Stages.

Pallant, J. (2007). SPSS survival manual: A step-by-step guide to data analysis using SPSS (Edisi ke-3). Sydney, Australia: Allen \& Unwin.

Poudyal, S., Neupane, M., \& Lopchan, M. (2014). Knowledge on prevention of complications related to immobility among caregivers of orthopedic patients at selected hospitals of Chitwan district. Journal of Chitwan Medical College, 4(3), 9-12. https://doi.org/10.3126/jcmc.v4i3.11932.

Reddy, M., Gill, S. S., \& Rochon, P. A. (2006). Preventing pressure ulcers: a systematic review. Jama, 296(8), 974-984. doi:10.1001/jama.296.8.974.

Saghaleini, S. H., Dehghan, K., Shadvar, K., Sanaie, S., Mahmoodpoor, A., \& Ostadi, Z. (2018). Pressure ulcer and nutrition. Indian journal of critical care medicine: peer-reviewed, official publication of Indian Society of Critical Care Medicine, 22(4), 283. https://dx.doi.org/10.4103\%2Fijccm.IJCCM_277_17.

Sharma, U., Kaur, S., \& Singh, A. (2013). Knowledge, beliefs and practices of caregivers regarding home based bedsore care in Chandigarh, North India. J Postgrad Med Edu Res, 47(3), 138-143.

Shuk-Fan, T., Yip, J., Kit-Lun, Y., dan Yuen, M. C. W. (2016). Pressure ulcer wound care for elderly in home: A case report. Journal of Dermatology Research and Therapy, 2 (3): 1-5.

Stechmiller, J. K., Cowan, L., Whitney, J. D., Phillips, L., Aslam, R., Barbul, A., ... \& Stotts, N. (2008). Guidelines for the prevention of pressure ulcers. Wound Repair and Regeneration, 16(2), 151168.

Tier, C. G., Dias, A. L., Siniak, D. S., Lana, L. D., da Silva, J. J. S. \& Furtado, B. C. G. (2019). Knowledge of caregivers of elderly people about care with injuries caused by pressure, International Journal of Development Research. 09 (06), 28467-28471.

Turkoglu, N., \& Kilic, D. (2012). Effects of care burdens of caregivers of cancer patients on their quality of life. Asian Pacific Journal of Cancer Prevention, 13(8), 4141-4145. https://doi.org/10.7314/APJCP.2012.13.8.4141.

Vanderwee, K., Grypdonck, M., \& Defloor, T. (2008). Alternating pressure air mattresses as prevention for pressure ulcers: A literature review. International journal of nursing studies, 45(5), 784-801. https://doi.org/10.1016/j.ijnurstu.2007.07.003.

Wani, A.M dan Malik, N.H (2013). Pattern of Medical Illnesses, Complications and Morbidity in Bedridden Hospitalized Patients in a Secondary Care Hospital in Makkah Region. Journal of Medicine and Medical Sciences, 4(11): 410-416.

Wound, O. (2017). WOCN 2016 Guideline for Prevention and Management of Pressure Injuries (Ulcers). Journal of Wound, Ostomy and Continence Nursing, 44(3), 241-246. https://doi.org/10.1097/WON.0000000000000321.

Wright, K. (2011). The Doctor's Guide to Pressure Ulcers: Prevention and Treatment. Mediscript Communications Inc.

Yoshikawa, T. T., Livesley, N. J., \& Chow, A. W. (2002). Infected pressure ulcers in elderly individuals. Clinical infectious diseases, 35(11), 1390-1396. 